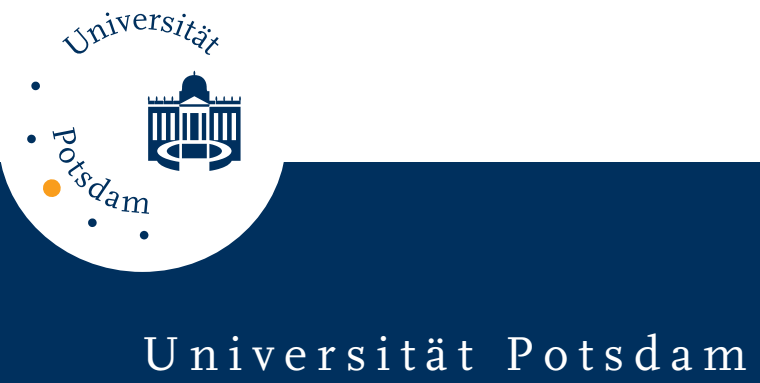

Barbara Krahè

\title{
Victim and observer characteristics as determinants of responsibility attributions to victims of rape
}

first published in:

Journal of Applied Social Psychology, 18 (1988) 1, S. 50-88

Postprint published at the Institutional Repository of Potsdam University:

In: Postprints der Universität Potsdam

Humanwissenschaftliche Reihe ; 69

http://opus.kobv.de/ubp/volltexte/2009/3383/

http://nbn-resolving.de/urn:nbn:de:kobv:517-opus-33833

Postprints der Universität Potsdam

Humanwissenschaftliche Reihe ; 69 


\title{
VIctim and Observer Characteristics as Determinants of Responsibillty Attributions to Viclims of Rape'
}

\author{
BARBARA KRAHÉ \\ The University of Sussex, Brighton, England
}

\begin{abstract}
Two field studies were conducted to investigate the influence of observer and victim characteristics on attributions of victim and assailant responsibility in a rape case. In the first study, male and fermale subjects completed a measurc of rape myth acceptance and were presented with a rape account after which they were asked 10 attribute responsibility to victim and assailant. In the second study, a new sample was asked to attribute responsibility to victim and assailant on the basis of one of two rape accounts in which victim's pre-rape behavior was manipulated. Results showed that both rape myth acceptance and victims 'pre-rape behavior influcneed the degree of responsibility attributed to victims and assnilants. No significant effects of subject gender were found. A more complex conceptualization is suggested of the link between observer and victim characteristics in social reactions 10 and evaluations of rape victims.
\end{abstract}

The claim by feminist writers (e.g., Brownmiller, 1975) and victim counsellors (e.g., London Rape Crisis Centre, 1984) that commonly held stereotypes about rape create a climate of hostility and suspicion toward victims of rape has recently received support from social psychological evidence. A person's readiness to endorse certain "rape myths" specifying stereotypic beliefs about victims, attackers, and circumstances of rape has been shown to be one of the most powerful factors on the observer side affecting social and, to some extent, legal evaluations of rape victims and their claims (e.g., Feild, 1978; Mazelan, 1980; Russell, 1984). Burt and Albin (1981) demonstrated that the likelihood of subjects 'defining a given account of coercive sexual intercourse as rape decreased as subjects' readiness to endorse stereotypic beliefs about rape increased. Their finding that belief in rape myths entails more restrictive rape definitions was also found by Feild (1978), who studied samples of police officers and adult citizens. On the behavioral side, rape myth acceptance has been linked to men's aggression toward women by' Briere and Malamuth (1983) and Malamuth and Check (1985), who report a positive relationship between rape myth acceptance and rape proclivity in males.

Thus, there is convincing evidence that beliefs in rape myths not only

\footnotetext{
'The author is now at the University of Mainz, IVest Germany. The present research was facilitated by' a fellow'ship from the Alexander von Humboldt-Foundation, livest Germany.

${ }^{2}$ Requests for reprints should be addressed 10 Barbara Krahé, Department of Psychology, University of Mainz. Postlach 3980, 6500 Mainz, West Germany.
} 
influence the perception and interpretation of rape incidents, but may in fact be conducive to sexual assault on women. A critical component of rape myth beliefs is the generally accepted view of what constitutes appropriate conduct for women. Victims who appear to have violated these rules of conduct by engaging in occupations, activities, or behavioral patterns regarded as inappropriate or incompatible with the female role are more readily seen as having precipitated the attack or being at least partly responsible for their fate. Studies by Best and Demmin (1982), Cann, Calhoun, and Selby (1979) and Luginbuhl and Mullin (1981) suggest that even information unrelated to and irrelevant for an evaluation of the specific case does affect attributions of blame and responsibility.

To investigatc the impact of rape myth acceptance and differential information about victim's behavior on attributions of responsibility to victim and assailant, two studies were conducted. The first study examined the conceptual validity and reliability of Burt's (1980) rape myth acceptance scale with a British sample. On this basis, the second study investigated the interaction between victims' role-related behavior and observers' attitudes about rape as determinants of responsibility attributions to rape victims. Both studies were conducted in a field setting in which ordinary beliefs and attitudes about rape were addressed.

\section{Study 1}

The first study aims to extend the scope of previous research in two ways: (a) by introducing responsibility attribution as a dependent variable that should be critically sensitive to rape myth beliefs; and (b) by investigating the validity of the concept of rape myth acceptance in a different cultural setting.

It is hypothesized that persons scoring high on rape myth acceptance will attribute more responsibility to the victim of a specific rape incident and less responsibility to the assailant than persons scoring low on rape myth acceptance. With regard to subject gender, evidence from previous studies suggests that males tend to attribute greater responsibility to the victim than females (e.g., Howells, et al., 1984; Thornton \& Ryckman, 1983; Tieger, 1981). To examine the conceptual link between subject gender and rape myth acceptance, the present study includes gender as a further independent variable.

\section{Method}

Subjects. Thirty-five male and 37 female members of the Brighton general public participated on a voluntary basis. They were approached at public places such as railway stations and shopping centers. In order to ensure that 
the sample was roughly homogeneous in terms of age, only people in the age range of 20 to 35 were approached. The average age was 25.2 years.

Procedure. Subjects were asked to complete a questionnaire that contained the 19-item Rape Myth Acceptance Scale (RMAS) by Burt (1980) and a brief rape vignette. The rape vignette was based on an authentic case reported by Sanders (1980, p. 43). The order of presentation of the RMAS and the rape vignette was balanced across subjects.

Following the rape vignette, respondents were asked whether the victim had any responsibility for the rape. Only those subjects who perceived some form of victim responsibility were asked to indicate the amount of responsibility on a $0-100 \%$ rating scale with decimal subdivisions. ${ }^{3}$ Assailant responsibility was also rated on a $0-100 \%$ scale.

\section{Resulis}

As the RMAS was originally developed in the U.S., its reliability for a British sample had to be examined first. An average corrected item-total correlation of .46 (Burt, 1980, p. 223: .51) and a Cronbach's alpha of .849 (Burt: .875) were obtained, thus warranting the use of the RMAS as a means of classifying subjects as either high or low on rape myth acceptance by median split.

A one-way analy'sis of variance with subject gender as independent variable was then conducted on rape myth acceptance. This analysis showed no significant effect and provided the basis for including the two variables as cparate factors into the analysis of the attributional data.

the 72 subjects, 6 males and 8 females assigned responsibility to the victim on the yes/no attributional measure. The remaining subjects denied any' responsibility on the victim's part. They were assigned a percentage score of "zero" on the subsequent rating scale of victim responsibility.

Separate $2 \times 2$ factorial analyses of variance with rape myth acceptance and subject gender as independent variables were performed on the percentage ratings for victim and assailant responsibility. Results showed a significant main effect of rape myth acceptance on ratings of victim responsibility, $F(1$, $68)=6.02, p<.02$. Neither the main effect for subject gender nor the interaction were significant. The cell means underlying this analysis are presented in Table 1. The analy'sis for ratings of assailant responsibility, based on the means presented in Table 2, also produced a significant main effect for

\footnotetext{
'This procedure was chosen after a pretest of the materials revealed that subjects were unhappy with being forced 10 allocate a percentage score to the victin. They saw this format as presupposing a certain amount of victim responsibility in any case, providing no option for a straightforward denial of victim responsibility. Thus, in order to avoid spuriously high responsibility ratings. a dicholomous yes/no question was included to precede the percentage scale.
} 
Table 1

Mean Ratings of Victim Responsibility' as a Function of Rape 'My'th Acceptance and Subject Gender

\begin{tabular}{cccc}
\hline Subject gender & & Male & Female \\
\hline $\begin{array}{l}\text { Rape myth } \\
\text { acceptance }\end{array}$ & High & 11.58 & 10.00 \\
\cline { 2 - 4 } & Low & 0.00 & 2.89 \\
\hline
\end{tabular}

rape myth acceptance, $F(1,68)=13.2, p<.001$. Again, neither the main effect for subject genषer nor the interaction were significant.

\section{Discussion}

The present findings support the validity of the concept of rape myth acceptance in accounting for differences in subjects' attributions of responsibility to rape victims and assailants. General beliefs about rape provide a frame of reference that guides the evaluation of specific rape incidents. To the extent that subjects accept the stereotypical beliefs about rape addressed in the RMAS, they tend to emphasize the victim's responsibility for the attack. Gender itself does not appear to be a psychologically relevant variable in this attributional process. Although this finding is at odds with those previous studies that demonstrated a significant relationship between gender and attributions of victin responsibility, it corroborates results from a German sample (Krahé, 1985) and also ties in with Burt's (1980) findings concerning antecedents of rape myth acceptance where highly similar patterns of relationships were obtained for male and female subjects. This apparent inconclusiveness of the cvidence on gender effects may be due, in part, to the fact that the studies demonstrating a greater tendency of males to attribute responsibility to rape

Table 2

Mean Ratings of Assailant Responsibility as a Function of Rape $M y t h$ Acceptance and Subject Gender

\begin{tabular}{cccc}
\hline Subject gender & & Male & Female \\
\hline $\begin{array}{l}\text { Rape myth } \\
\text { acceptance }\end{array}$ & High & 87.63 & 82.22 \\
\cline { 2 - 4 } & Low & 99.38 & 99.21 \\
\hline
\end{tabular}


victims did not include measures of rape-related attitudes. Thus, it may be argued that gender effects materialize only so long as more specific intormation as to subjects' attitudes about rape is not taken into account.

\section{Study' 2}

This study seeks to explore the relationship between rape myth acceptance and differential information about the victim as determinants of responsibility altributions. Most previous research on the effects of victim information addressed the impact of the woman's respectability in terms of marital or occupational status (e.g., Jones \& A ronson, 1973). In one of the few studies where behavioral information about the victim was given, Best and Demmin (1982) demonstrated that victims who were seen as engaging in behaviors defined as provocative or nonconforming to the female role were attributed more blame than victims seen as engaging in nonprovocative or roleconforming behavior.

Following Best and Demmin's (1982) line of reasoning, this study extends their approach by including rape myth acceptance as a relevant observer variable. Two hypotheses are advanced:

(1) The victim who is engaged in role-discrepant behavior prior to the rape is attributed greater responsibility than the victim who is engaged in roleconforming behavior.

(2) High rape myth acceptance leads to greater responsibility attributed to the victim, especially to the victim engaging in role-discrepant behavior.

Subject gender is again included as an independent variabic to examine whether the lack of gender effects in Study 1 is replicated with an independent sample.

\section{Melhod}

Subjects. Thirty-six males and 37 females volunteered to participate in the study. All participants were members of the Brighton general public in the age range of 201035 who were approached at various public places. The average age was 26.4 years.

Procedure. Subjects were presented with a questionnaire containing either the role-conforming or the role-discrepant version of a rape vignette. The vignette was the same as in Study 1 except for the variation of victim's pre-rape behavior. This was contained in the introductory'sentence that read either "After having finished work in her office, the victim was on her way to the car park where her car was parked," or "After having had a drink on her own in a pub, the victim was on her way to the car park where her car was parked." The text then described the rape incident. 
Subjects indicated victim and assailant responsibility on the same measures as in Study 1. They then completed the Rape Myth Acceptance Scale.

\section{Results}

First, it was established through a one-way analysis of variance that rape myth acceptance scores were not systematically affected by the different versions of the rape vignette presented prior to the RMAS. Because information about victim's pre-rape behavior showed no significant effect on rape myth acceptance, all subjects were classified as either high or low on rape myth acceptance by median split.

Eight males and 9 females assigned responsibility to the victim on the yes/no attributional measure. The remaining 56 subjects denied any responsibility on the victim's part and were assigned a score of "zero" on the percentage scale of victim responsibility.

Separate $2 \times 2 \times 2$ analyses of variance were performed for victim and assailant responsibility with subject gender, rape myth acceptance, and victim's role conformity as independent variables. The cell means for ratings of victim responsibility are presented in Table 3 . The analysis of variance produced a highly significant main effect for rape myth acceptance, $F(1,65)=$ $12.32, p<.001$, and a significant interaction between victim's role conformity and subjects' rape myth acceptance, $F(1,65)=4.26, p<.05$, indicating that differential information about victim's pre-rape behavior only' affected the attributions of subjects scoring high on rape myth acceptance. None of the remaining main effects and interactions were significant.

Mean ratings of assailant responsibility are given in Table 4 . The only significant effect was the interaction between victim's role conformity and subjects' rape myth acceptance, $F(1,65)=6.31, p<.02$ : Subjects high on

\section{Table 3}

Mean Ratings of V'ictim Responsibility' as a Function of Victini's Pre-rape Behavior, Subject Gender, and Rape Myth Acceptance

\begin{tabular}{ccccccc}
\hline Subject gender & \multicolumn{2}{c}{ Male } & \multicolumn{2}{c}{ Female } \\
\hline Rape myth acceptance & High & Low & High & Low \\
\hline Viclims & $\begin{array}{c}\text { Role- } \\
\text { conforming } \\
\text { Role- }\end{array}$ & 6.25 & 0.00 & 3.75 & 1.67 \\
\cline { 2 - 6 } & pre-rape behavior & 15.45 & 0.00 & 17.00 & 0.00 \\
\hline
\end{tabular}


Table 4

Mean Ratings of Assailant Responsibility as a Function of Victim's Pre-rape Behavior. Subject Gender, and Rape Myth Acceptance

\begin{tabular}{|c|c|c|c|c|c|}
\hline \multirow{2}{*}{\multicolumn{2}{|c|}{$\frac{\text { Subject gender }}{\text { Rape myth acceptance }}$}} & \multicolumn{2}{|c|}{ Male } & \multicolumn{2}{|c|}{ Female } \\
\hline & & High & Low & $\mathrm{High}$ & Low \\
\hline \multirow{2}{*}{$\begin{array}{l}\text { Victim's } \\
\text { pre-rape behavior }\end{array}$} & $\begin{array}{c}\text { Role- } \\
\text { conforming }\end{array}$ & 94.38 & 86.25 & 96.25 & 93.33 \\
\hline & $\begin{array}{c}\text { Role- } \\
\text { discrepant }\end{array}$ & 84.55 & 97.78 & 73.00 & 97.86 \\
\hline
\end{tabular}

rape myth acceptance attributed more responsibility to the assailant than those low on rape myth acceptance when the victim had engaged in roleconforming behavior prior to the rape. The reverse pattern was obtained when the victim has behaved in a role-discrepant fashion.

\section{Discussion}

No support is obtained for the first hypothesis derived from Best and Demmin (1982), stating that differential information about victim behavior significantly' affects attributions. However, strong evidence is found for the second hy'pothesis postulating an interaction between victim's role conformity and subject's rape myth acceptance: People who accept stereotypic ideas about rape appear more ready to take victinis behavior into account as an aggravating or attenuating factor in assessing both victim and assailant responsibility. Thus, including a measure of rape myth acceptance allows more specific conclusions about the way in which information about the victim interacts with observer attitudes when the victim's role in a specific rape incident is evaluated. As in Study 1, there is no evidence of gender effects on responsibility attributions.

\section{General Discussion}

Results from the two studies strongly suggest that rape myth acceptance is a critical determinant of responsibility attributions 10 rape victims and assailants. A person's general attitude about what constitutes rape and under what circumstances it can occur at all systematically influences his or her evaluation of a specific rape incident.

A second variable shown to affect responsibility attributions concerns 
information about the victim's behavior prior to the attack. Although the rape vignettes contained no implication that victim pre-rape behavior was in any way related to the subsequent attack, subjects high on rape myth acceptance did utilize this information in their responsibility attributions. This finding lends further support to the conceptual validity of rape myth acceptance: Only for those individuals who rely on stereotypic beliefs about rape when asked to evaluate a specific case does victim pre-rape behavior constitute a relevant piece of information.

These findings suggest a more complex interpretation of the psychological processes involved in the social evaluation of rape viclims and offenders than has been offered in the past. A strong point has been made by previous authors about the pervasive tendency of observer attributions being critically affected by information about the victim (e.g., Borgida \& White, 1979; FeldmanSummers \& Lindner, 1976; Smith, Keating, Hester, \& Mitchell, 1976). However, none of these studies incorporated rape myth acceptance as an attitudinal variable, thereby failing to address the crucial question of the psychological functions that that type of information about the victim may or may not serve for the observer.

Moreover, the failure of the present studies to find evidence for gender differences in both rape myth acceptance and responsibility attributions speaks against a simple currespondence between gender and restrictive vs. sympathetic judgments of rape victims. It is not male attitudes but stereotypic rape myths held across the genders that have to be changed in the social perception of victims of rape.

\section{References}

Best, J. B., \& Demmin, H. S. (1982). V'ictim's provocativeness and victim's altractiveness as determinants of blame in rape. Ps!chological Reports, 51 , 255-258.

Borgida, E., \& White, P. (1978). Social perception of rape victims. Law and Human Behavior, 2, 339-352.

Briere, J., \& Malamuth, N. M. (1983). Self-reported likelihood of aggressive behavior:..Attitudinal versus sexual explanations. Journal of Research in Personality, 17, 315-323.

Brownmiller, S. (1975). A gainst our will: Men, women and rape. New York: Simon \& Schuster.

Burt, M. R. (1980). Cultural myths and support for rape. Journal of Personalit!' and Social Ps!cholog!: 38, 217-230.

Burt, M. R., \& Albin, R. S. (1981). Rape myths, rape definitions, and probability of conviction. Journal of Applied Social Psychology: 11, 212-2.30. 
Cann, A., Calhoun, L. G., \& Selby, J. W. (1979). Attributing responsibility to the victim of rape: Influence of information regarding past sexual experience. Human Relations, 32, 57-67.

Feild. H. S. (1978). Attitudes toward rape: A comparative analysis of police, rapists, crisis counselors, and citizens. Journal of Personality and Social Psychology: 36, 156-179.

Feldman-Summers, S., \& Lindner, K. (1976). Perceptions of victims and defendants in criminal assault cases. Criminal Justice and Behavior, 3, $135-150$.

Howells, K., Shaw, F., Greasley, M., Robertson, J., Gloster, D., \& Metcalfe, N. (1984). Perceptions of rape in a British sample: Effects of relationship, victim status. sex, and attitudes to women. British Journal of Social Psychology: 23, 35-40.

Jones, C., \& Aronson. E. (1973). Attribution of fault to a rape victim as a function of respectability of the victim. Journal of Personality and Social Ps!cholog.1: 26, 415-419.

Krahé. B. (1985). Verantwortungszuschreibungen in der sozialen Eindrucksbildung über V'ergewaltigungsopfer und 7-ter. Gruppendynamik, 16, 169 178.

London Rape Crisis Centre (1984). Sexual violence. London: The Women's Press.

Rinbuhl. J., \& Mullin, C. (1981). Rape and responsibility: How and how much is the victim blamed? Sex Roles, 7, 547-559.

Malamuth. N. M.. \& Check, J. V. P. (1985). The effects of aggressive pronography on beliefs in rape myths: Individual differences. Journal of Research in Personalit!, 19, 299-320.

Mazelan. P. (1980). Stereotypes and perceptions of the victims of rape. Vicrimolog.: 5. 121-132.

Russell. D. E. (1984). Sexual exploitation. Beverly Hills, C.A: Sage.

Saunders. W. B. (1980). Rape and woman's identir!' Beverly Hills, CA: Sage. Smith. R. E., Keating, J. P., Hester, R. K., \& Mitchell, H. E. (1976). Role and justice considerations in the attribution of responsibility to a rape victim. Journal of Research in Personality, 10, 346-357.

Thornton. B.. \& Ryckman, R. M. (1983). The influence of rape victim's physical attractiveness on observers'attributions of responsibility. Human Relarions, 36, 549-562.

Tieger, T. (1981). Self-rated likelihood of raping and the social perception of rape. Journal of Research in Personality, 15, 147-258. 